\title{
Seismic Activity and Seismotectonic Correlation with Reference to Northeast India.
}

\author{
Pulama Talukdar ${ }^{1}$, N.C. Barman ${ }^{2}$ \\ 1. Department of Physics. Barbhag College, Kalag, Nalbari, Assam, India \\ 2. Department of Physics. Tihu College, Tihu, Nalbari, Assam, India
}

\begin{abstract}
Northeast India and its surrounding regions are seismically one of the six most active regions of the world which has experienced 19 large $(M \geq 7)$ including 3 great earthquakes $(M \geq 8)$. The region has five major tectonic domains having its own evolutionary history and characteristics. Seismicity and seismotectonic correlation of the region is studied by earthquake distribution pattern in different magnitude and depth relating to each tectonic domain dividing the area into five blocks. It has been observed that the Main Central Thrust $(M C T)$ and Main Boundary Thrust (MBT) along the line of collision between the Indian and Eurasian plate are predominant site of shallow earthquake events of the area to the north whereas Indo-Burma belt is the prime area of intermediate earthquakes evidencing the continuous subduction of Indian plate to the Burmese to the east. Besides intra plate activity in Shillong plateau and Mikir Hills is also shaking the region. The epicentral concentration around Kopili lineament clearly shows that this is the most active lineament of Assam valley.
\end{abstract}

Key words: Fault, Lineament, Seismicity, Seismotectonic, Thrust.

\section{Introduction:}

The distribution pattern of earthquakes in seismic zone is an important aspect to be considered in the study of the seismicity of the region. It depicts the areas of low and high seismic activity and thereby helps in identifying major faults and lineaments in the region. Generally most of the earthquakes occurred in an active seismic zone are tectonic origin. And hence there must be some correlation between the distribution of earthquakes and regional tectonics. Over a period of 30 years Nandy and his co-workers have carried out extensive research in seismotectonic of the Northeastern region of India. The region has collision tectonics between the Indian plate and the Eurasian plate in the north and subduction tectonic along the Indo-Burma range in the east $[1,2,3,4,5]$. Focal depth is also an important aspect of seismic study as shallower the earthquake, the more damage to the structure it causes, all else being equal. The shallow seismic activity is the effect of continental-continental collision and the subduction which is still continuing in the Indo-Burma region is evidenced by the intermediate to deep focus earthquake in this range [6]. The northeast India has experienced 19 large Earthquakes $(M \geq 7)$ including the great earthquakes of Shillong (1897, $M=8.7)$, Burma $(1912, M=8)$ and Assam-Tibet border $(1950, M=8.7)$. Moreover several hundreds small and micro earthquakes have also been recorded in the region. The distribution of earthquakes in this region, their concentration in different section of the area, classification on the basis of magnitude and depth and their correlation with the regional tectonics have been studied here.

\section{Seismotectonics:}

The northeastern region of India has five major tectonic domains each having own evolutionary history, characteristic pattern and Geometry of inter and intra domain dynamics of movements producing characteristic seismicity. Depending upon the tectonic setting, the study area is divided into five blocks: Block - A $\left(26.8^{0} \mathrm{~N}\right.$ to $29.5^{0} \mathrm{~N}$ and $88^{0} \mathrm{E}$ to $\left.95^{0} \mathrm{E}\right)$, Block- $\mathrm{B}\left(26.8^{0} \mathrm{~N}\right.$ to $29.5^{\circ} \mathrm{N}$ and $95^{\circ} \mathrm{E}$ to $\left.97.5^{0} \mathrm{E}\right)$, Block $-\mathrm{C}\left(21^{0} \mathrm{~N}\right.$ to $26.8^{0} \mathrm{~N}$ and $93.5^{\circ} \mathrm{E}$ to $\left.97.5^{0} \mathrm{E}\right)$, Block-D $\left(25^{0} \mathrm{~N}\right.$ to $26.8^{0} \mathrm{~N}$ and $88^{0} \mathrm{E}$ to $\left.93.5^{\circ} \mathrm{E}\right)$ and Block-E $\left(21^{0} \mathrm{~N}\right.$ to $25^{0} \mathrm{~N}$ and $88^{\circ} \mathrm{E}$ to $93.5^{\circ} \mathrm{E}$ ). Block-A comprises the eastern Himalayan range which is characterized by a series of north heading thrusts. Amongst these the important thrusts are the Main Boundary Thrust (MBT), Main Central Thrust (MCT) and Main Frontal Thrust (MFT). Block-B is also known as the Syntaxis Zone which is the meeting place of Himalayan and Burmese Arc. The main fracture of this zone is Mishmi Thrust, Lohit Thrust and a part of Disang Thrust. Block-C, the Indo-Burma range is characterized by Arakan Yoma, chin hills, Sagaing Fault and Schuppon Belt which mainly infested by Naga and Disang Thrust. Block-D comprises Shillong Massif, Mikir Hills, Tista Fault, Dhubri Fault, Kopili Lineament, Dapsy Thrust, a part of Naga Thrust and a part of Brahmaputra Fault. The southern margin of the Shillong Massif is characterized by the Dauki Fault which has been interpreted to have strike slip displacement by Evans [7]. Murthy et al. [8] considered it as a reverse fault whereas Molnar [9] interpreted it as a north heading thrust. The western margin is demarcated by the NS Yamuna Fault. There is a NS Grabben between the Shillong Massiff and Mikir Hills in the east along which the Kopili River flows north. Block-E comprises Bengal Basin, Tripura and Mizo Fold Belt. The main 
Seismic Activity and Seismotectonic Correlation faults of this zone are Padma Fault, Yamuna Fault, Kaladan Fault and Tapu Thrust.

\section{Data source and Methodology:}

A comprehensive data file prepared from United States Geological Survey (USGS) and International Seismic Center (ISC) catalog has been used to analyze the earthquake distribution pattern of the study region. A seismotectonic map with different blocks is prepared by superimposing the epicentral map with the magnitude $\geq$ $4 \mathrm{M}_{\mathrm{b}}$ for the time window 1964-2011 to the tectonic map [7, 10] of the region to study the relation between seismicity and regional tectonics (Fig. 1). Classification of earthquake events is made on the basis of magnitudes and depths. Magnitude wise classification has been made for the total number of 1571 events during the period $1964-2011$ for the ranges 4-4.9 $\mathrm{M}_{\mathrm{b}}, 5-5.9 \mathrm{M}_{\mathrm{b}}, 6-6.9 \mathrm{M}_{\mathrm{b}}$ and 7-7.9 $\mathrm{M}_{\mathrm{b}}$ while the depth wise classification has been made on the basis of the standard categories, that is shallow $(<70 \mathrm{~km})$, intermediate $(70-300 \mathrm{~km})$ and deep focus (300 -700 km) earthquakes during the period $1979-2011$ with the total number of 1395 events.

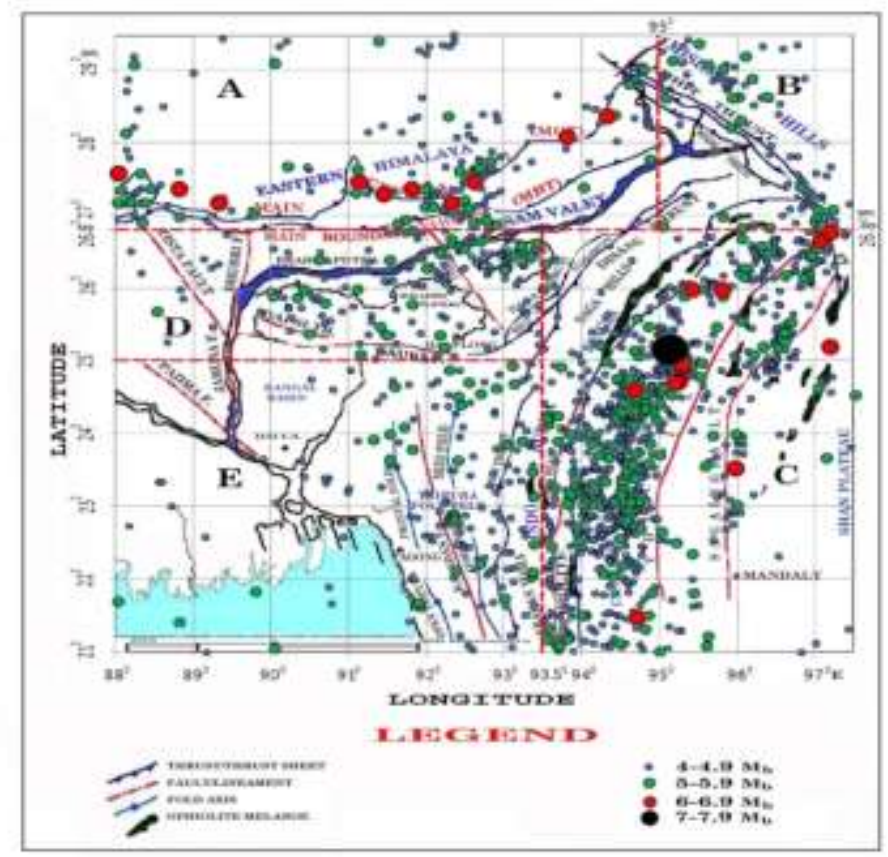

Figure 1: Seismotectonic map with block division of the study area during 1964-2011.

Tectonic setting of northeast India: after Evans [7] and Krishnan [10]

\section{Result and Discussion:}

\subsection{Classification of earthquake events:}

\subsubsection{Magnitude wise classification:}

Magnitude wise classification of earthquakes is presented in Table 1. The number of earthquakes is the highest in block C followed by block A, block E, block D and block B. During the study period the entire area has experienced only one earthquake having magnitude $\geq 7 \mathrm{M}_{\mathrm{b}}$ in block $C$. The number of earthquakes in magnitude range $6-6.9 \mathrm{M}_{\mathrm{b}}$ is almost same in block $\mathrm{A}$ and block $\mathrm{C}$ while other blocks have no earthquakes in this range. Number of earthquakes in magnitude range 5-5.9 $\mathrm{M}_{\mathrm{b}}$ is almost equal in block $A$ and Block $E$ but it is one third of block $C$. In magnitude range 4-4.9 $\mathrm{M}_{\mathrm{b}}$ the number of events are almost equal in block $\mathrm{A}, \mathrm{D}$ and $\mathrm{E}$ while it is nearly five times high in block C. Events observed in block B in all magnitude ranges are too low compared to the others. This may be due to poor coverage of seismic monitoring stations in an around this block. Bar Diagram showing seismic distribution in each block with different magnitude of the study area is presented in Fig.2.

\subsubsection{Depth wise classification:}

The number of earthquakes of different magnitude classes having shallow and intermediate depths is presented in Table 2. No deep focus earthquakes have been found in the entire area. It has been observed that for each magnitude range the number of shallow focus earthquakes is more than the intermediate focus earthquakes in the whole region but if hypocentral distribution is studied block wise it is observed that intermediate focus earthquakes are predominant in block $\mathrm{C}$ as presented in table 3. Hypocentral distribution of the earthquake in relation to regional tectonics is depicted in Fig. 3. 
Table-1: Number of earthquakes in different magnitude ranges in different blocks.

\begin{tabular}{|c|c|c|c|c|c|c|}
\hline \multirow{2}{*}{$\begin{array}{c}\text { Mag. } \\
\text { Range in } \\
\text { Mb }\end{array}$} & \multicolumn{6}{|c|}{ Number of Earthquakes from 1964 to 2011 } \\
\cline { 2 - 7 } & $\begin{array}{c}\text { Block } \\
\text { A }\end{array}$ & $\begin{array}{c}\text { Block } \\
\text { B }\end{array}$ & $\begin{array}{c}\text { Block } \\
\text { C }\end{array}$ & $\begin{array}{c}\text { Block } \\
\text { D }\end{array}$ & $\begin{array}{c}\text { Block } \\
\text { E }\end{array}$ & Total \\
\hline $4-4.9$ & 141 & 69 & 803 & 128 & 128 & 1269 \\
\hline $5-5.9$ & 44 & 22 & 189 & 29 & 35 & 319 \\
\hline $6-6.9$ & 10 & 0 & 12 & 0 & 0 & 22 \\
\hline $7-7.9$ & 0 & 0 & 1 & 0 & 0 & 1 \\
\hline Total & 195 & 91 & 965 & 157 & 163 & 1571 \\
\hline
\end{tabular}

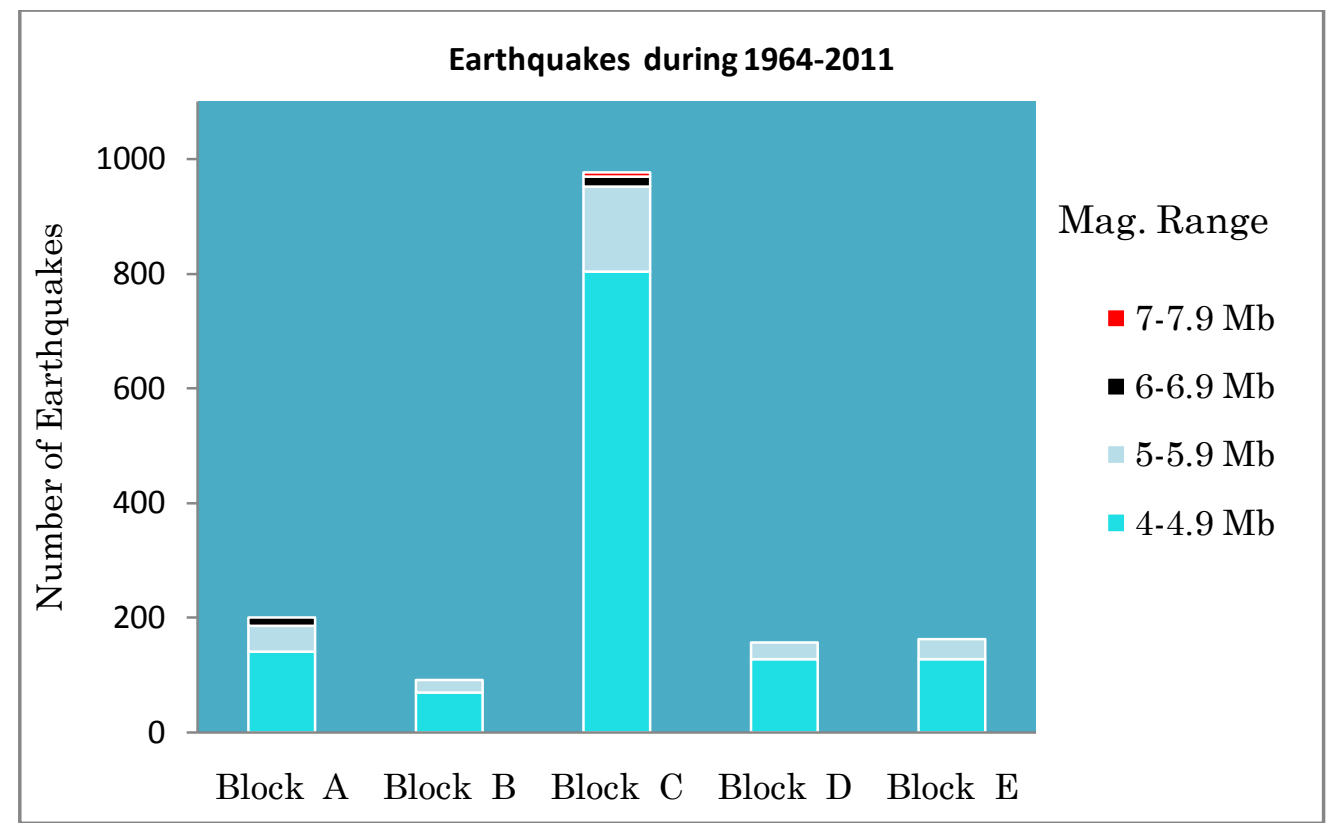

Figure 2: Bar Diagram showing seismic distribution in each block with different magnitude of the study area.

Table-2: Number of Earthquakes in different magnitude ranges in different depths.

\begin{tabular}{|c|c|c|c|c|c|}
\hline \multicolumn{6}{|c|}{ Depth wise Classification of Earthquakes from 1979 to 2011} \\
\hline \multirow[t]{2}{*}{ Depth in $\mathrm{km}$} & \multicolumn{4}{|c|}{ No. of Earthquake } & \\
\hline & $\mathrm{M}=4-4.9$ & $M=5-5.9$ & $\mathrm{M}=6-6.9$ & $\mathrm{M}=7-7.9$ & Total \\
\hline $0-<70$ & 735 & 147 & 5 & 0 & 887 \\
\hline $70-300$ & 447 & 56 & 4 & 1 & 508 \\
\hline$>300$ & 0 & 0 & 0 & 0 & 0 \\
\hline Total & 1182 & 203 & 9 & 1 & 1395 \\
\hline
\end{tabular}

Table-3: Number of Earthquakes in different blocks in different depths.

\begin{tabular}{|c|c|c|c|c|c|}
\hline \multirow{2}{*}{$\begin{array}{c}\text { Depth range in } \\
\mathrm{km}\end{array}$} & \multicolumn{5}{|c|}{ Different blocks } \\
\cline { 2 - 6 } & $\mathrm{A}$ & $\mathrm{B}$ & $\mathrm{C}$ & $\mathrm{D}$ & $\mathrm{E}$ \\
\hline $0-<70$ & 164 & 72 & 377 & 137 & 137 \\
\hline $70-300$ & 5 & 4 & 487 & 3 & 9 \\
\hline Total & 169 & 76 & 864 & 140 & 146 \\
\hline
\end{tabular}

\subsection{Seismotectonic Correlation:}

Seismicity in block-A comprising eastern Himalayan zone is due to collision tectonics between the Indian plate and the Eurasian plate [11, 12]. The number of earthquakes reported from this block is 195. Among these 10 events are in the magnitude range 6-6.9 $\mathrm{M}_{\mathrm{b}}$ and almost all these events are located along MBT and 
Seismic Activity and Seismotectonic Correlation

MCT which indicated that most of the major Himalayan earthquakes occur due to movements along these thrusts. But 1980 Gangtok earthquake having magnitude $>6 \mathrm{M}_{\mathrm{b}}$ had well constrained focal depth of $47 \mathrm{~km}$ yielding clear strike-slip solution [13]. This earthquake neither could have been generated by thrust movements,

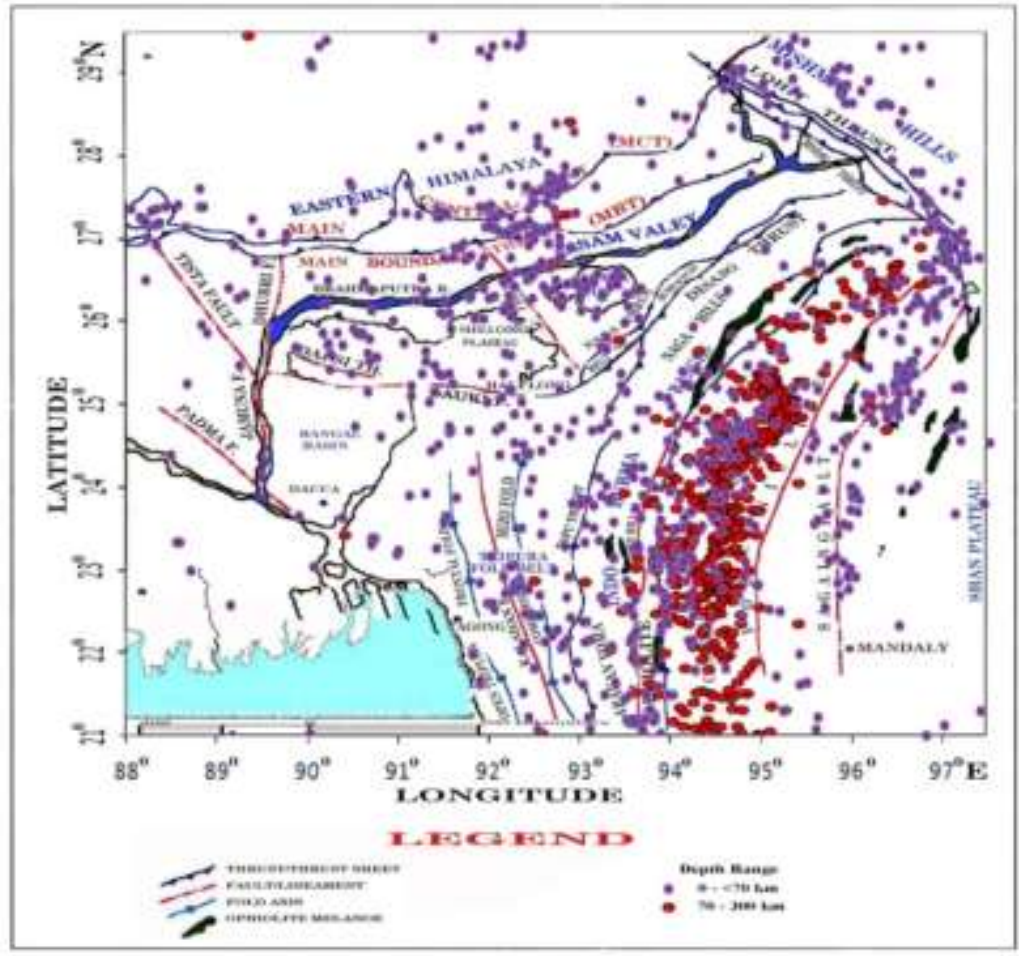

Figure 3: Hypocentral distribution of Earthquakes in relation to Tectonic Setting.

nor that had been possible for any thrust tectonics in the Himalayan setting to produce such deep focus earthquake events [14].Five other intermediate focus earthquakes are reported from this zone during the study period. Earthquakes of magnitude $\leq 5 \mathrm{M}_{\mathrm{b}}$, however not always correlated with MCT and MBT. Other important transverse faults of the Himalayan trend arc are MFT, Kanchen Dzonga, Yadaon Gulu (graben), Tista, Yamuna, Dudhnoi, Kulsi, Gyau (graben), Kapili and Bomdila Faults. Seismotectonic analysis of this region $[13,15]$ has clearly indicated that these faults are active at present. Block-B, the syntaxis zone has experienced 91 earthquakes during this period. No earthquake having magnitude $\geq 6 \mathrm{M}_{\mathrm{b}}$ has been reported from this block. The seismic events are spread over the whole region. A clustering of earthquake has been observed in the southeast part of the block. This tectonic block is traversed by some important high angle thrusts from foot hill to the higher Himalayan domain. These are Mishmi thrust, Tiding suture, Lohit thrust and Po Chu Fault. The frontal Mishmi thrust overrides the NE trending fold and thrust belt of the Indo-Myanmar mobile belt. The 1950 great Assam earthquake $(M>8)$ occurred in the Po Chu Fault zone which is located in the NW extremity of the Mishmi massif. This event indicated both dextral slip along NW nodal plan and thrust movements by different workers [16]. The earthquake events occurring right inside the Mishmi block had yielded strike slip solutions indicating thereby that present tectonic transport is mainly through strike slip motion [14]. Most of the seismic events in this zone are shallow focused with depth $<40 \mathrm{~km}$, but few events have focal depth $>70 \mathrm{~km}$. Block-C, comprising the Indo-Myanmar Subduction zone, is the seismically most active zone of the northeast India. In 1988 the region experienced a large earthquake of magnitude $7.3 \mathrm{M}_{\mathrm{b}}$ at the location of $25.15^{\circ} \mathrm{N}$ and $95.13^{\circ} \mathrm{E}$ in the upper part of Central Burma basin, between Arakan Yoma in the west and the Volcanic line in the east with the focal the depth $90 \mathrm{~km}$. Total number of 965 seismic events are reported from this block. Among these 12 events are in the magnitude range 6-6.9 $\mathrm{M}_{\mathrm{b}}, 149$ in 5-5.9 $\mathrm{M}_{\mathrm{b}}$ and 803 in 4-4.9 $\mathrm{M}_{\mathrm{b}}$. The line of concentration of the epicenters is just east of the eastern boundary thrust (EBT) which signifies an oblique subduction towards the east. Epicentral density decreases away from the EBT on both sides. This thrust represents the surface trace of the subduction interface. Moreover a clustering of events has been observed between the latitude $22^{\circ} \mathrm{N}$ and $25^{0} \mathrm{~N}$ which is the central portion of the belt, where EBT takes a bend towards east. Along the Shan Sagaing fault on Burmese side seismic activity is quite high. This fault delimits the eastern boundary of Central Myanmar Molasse Basin. Seismotectonic analysis indicates active dextral slip along the Shan Sagaing fault. Seismic activity seems to be low in the Schuppon belt in the Naga Hills. The events experienced are mostly intermediate in this region. Most of the intermediate focus earthquakes in Burma indicate the probable existence of a subduction zone underneath the Arakan Yoma and Burmese plains. The depth of focus in this zone goes up to $200 \mathrm{~km}$ south of $26^{\circ} \mathrm{N}$ latitude, and north of this, the depth becomes lesser. In the north of this latitude, i.e. in 
Seismic Activity and Seismotectonic Correlation

the Naga Hills, seismicity becomes shallow due to the collision process [17, 1]. From Block - D, comprising Shillong plateau, Mikir Hills and a part of Assam valley, total no of 157 events has been reported. 128 events have magnitude in the range 4-4.9 $\mathrm{M}_{\mathrm{b}}$ while only 29 events are in the magnitude range 5-5.9 $\mathrm{M}_{\mathrm{b}}$. The events are spread over the whole region but mostly concentrated in Shillong plateau and near Kopili lineament. The intraplate earthquakes of Shillong plateau is explained by pop- up tectonic. The Kopili fault zone, approximately $300 \mathrm{~km}$ long and $30 \mathrm{~km}$ wide, separate the Shillong plateau and Mikir massif by strike slip movement and it is identified as the most active fault in the Assam valley area [18, 19]. Seismotectonic analysis carried out Nandy and Dasgupta in 1991[15] and Nandy in 2005[20] indicate the probability of large earthquake in this zone in near future. This Kopili fault was responsible for 1869 Cacher earthquake as well as the 1943 event (M > 7). The $200 \mathrm{~km}$ long EW Dauki fault defining the southern margin of the Shillong plateau had been active since Cretaceous to the Recent. At present this fault seems to be dormant [16]. The prominent structural discontinuities in the region are Dudhnoi, Kulsi and Bomdila faults. The movement along the Dudhnoi fault produced 1897 great Assam earthquake $(\mathrm{M}>8)$. The earthquake events located in Shillong plateau, MIkir Hills and the adjoining areas indicated strike slip motion with $\mathrm{N}, \mathrm{NW}$ and $\mathrm{NE}$ directed pressure axes $[15,21]$. In this region most of the seismic events are of shallower depth. Only three events of focal depth $>70 \mathrm{~km}$ have been observed here. 163 events are reported from the block E comprising Bengal basin and Tripura- Mizoram folded belt. Most of the events (128) have smaller magnitude. Only 35 events in magnitude range 5-5.9 $\mathrm{M}_{\mathrm{b}}$ are reported. The events are mostly spread over the Tripura and Mizo-fold belt which indicates that this belt is seismically more active. The seismic activity of Bengal basin may be related to intra plate activity while that of Tripura and Mizo- fold belt may be related to plate boundary activity. EW trending Dauki fault that demarcates the boundary between Shillong plateau and Bengal basin, NW-SE Padma lineament, NS Yamuna fault, Taipui fault, Mat fault and Kaladan fault are the important discontinuity of this region. The 1918 Srimangal earthquake $(M=7.6)$ originated beneath the Bengal basin due to rupture along the high angle reverse Sylhet fault where it is intersected by NW trending Mat fault. Cachar earthquake of 1984, $(M=6)$ occurred in the Tripura fold belt. Most of the earthquake in this region has shallow focal depth.

\section{Conclusion:}

A clear alignment of epicenter with different faults, lineaments and thrusts are obtained from the study of seismicity and seismotectonics of northeast India which depicts their tectonic activity. Some clustering of event is observed between MCT and MBT, towards the north of Kopili lineament, in Shillong plateau and Mikir Hills, near Lohit and Mishmi thrust and in Central Burma basin. The highly concentrated events indicate that Central Burma basin is most active region of northeast India where subduction process is going on. The epicentral concentration around Kopili lineament, which was responsible for Cachar earthquakes (M > 7) of 1869 and 1943, clearly shows that this is the most active lineament of Assam valley and this may be the source of another large earthquake in near future. In the eastern syntaxis zone which was the seat of 1950 great Assam earthquake no appreciable seismic activity is observed during last 60 years which may be considered as quiescence period prior to occurrence of a large magnitude earthquake. Depth wise distribution of earthquake events shows that the Shillong plateau and Mikir Hills indicate shallow seismic activity. Occurrence of the large magnitude earthquakes at shallow depth may be the cause of fatal destruction of the region. As intermediate seismicity is predominant in the most active Indo-Burma range, large magnitude events may not lead to much destruction in this region.

\section{Acknowledgement}

We are thankful to Gauhati University Library Authority for giving the permission to use the Reference Section as well as the Digital Library and the Department of Physics, Barbhag College, Nalbari, Assam for helping in preparing the manuscript.

\section{Reference:}

[1] J.R. Kayal, Earthquake source process in North East India: A review, Him. Geol., 17, 1996, 53-692

[2] J.R. Kayal, Seismicity of Northeast India and surroundings- development over the past 100 years, Jour. Of Geophysics, 19(1), 1998, 9-34.

[3] P. Molnar, and P. Taponnier, Cenozoic tectonics of Asia, Effects of continental collision, Science, 189, 1975, 419-426

[4] S. Baruah, Yadav, K. Dilip, Duarah, Ranju and MVD, Sitaram, Pattern of seismicity and the orientation of principal compressive stress: An approach towards seismic hazard estimation in NER, India, Proc. Workshop on earthquake Disaster Preparedness, Oct. 13-14, Roorkee, 19967

[5] S.K .Sarmah, the probability of occurrence of a high magnitude earthquake in Northeast India., Jour. Of Geophysics 20(3), 1999, 129-135.

[6] S. Baruah, and D. Hazorika, A GIS based tectonic map of Northeastern India, Current Science, 95(25), 2008

[7] P. Evans, Tectonic Framework of Assam. Jour. Geol. Soc. India 5, 1964 pp. 80-96

[8] M.V.N. Murthy, S.N Talukdar, A.C. Bhattacharya, C. Chakraborty, The Dauki Fault of Assam, Bull. O.N.G.C. 6(2), 1971 pp.5764.

[9] P. Molnar, The Distribution of Intensity Associated with the 1905 Kangra Earthquake and Bound on the Extent of Rupture Zone, J. Geol. Soc. India 29, 1987 pp. 221-229. 
Seismic Activity and Seismotectonic Correlation

[10] M.S. Krishnan, Geology of India and Burma, Higgin Bothams, Madras, 1960, 553pp.

[11] R.K. Verma, and M. Mukhopadhyay, An analysis of gravity field in Northeastern India, Tectonophysics. 42, 1977, $283-317$.

[12] K.N. Khattri, and A.K. Tyagi, Seismicity patterns in the Himalayan plate boundary and identification of areas of high seismic potential. Tectonophysics, Vol. 96, 1983, pp. 281-297.

[13] S. Das Gupta, M. Mukhopadhyay, and D.R. Nandy, (1987): Active tectonic features in the central part of the Himalaya: Tectonophysics, vol. 136, 1987, pp 255-264.

[14] D. Nandy, Seismotectonics of northeastern India with special reference to Earthquake hazard, International Workshop on Earthquake Hazards and Mitigation, Guwahati, India. 7-8 Dec, 2007.

[15] D.R. Nandy, and S. Dasgupta, Seismotectonic domains of northeastern India and adjacent areas. Geology and Geodynamics of Himalayan collision zone, 2, Physics and Chemistry of Earth, 18, 1-11, Pergamon Press, PLC, Oxford,1991, 371-384.

[16] D.R. Nandy, Geodynamics of Northeastern India and the adjoining region (acb Publication, Kolkata, pp 1-209 Geological Survey of India, 2001

[17] J.R. Kayal, (1987): Microseismicity and source mechanism study: Shillong plateau, North East India, Bull. Seismological Society of America, 77: (1), 1987, 184-194

[18] J.R .Kayal, S.S. Arefiev, S. Baruah,D. Hazarika, N. Gogoi, A. Kumar,S.N. Chowdhury, and S. Kalita, Shillong Plateau earthquakes in Northeast India region: Complex tectonic model Current Science 91 (1), 2006, 109-114.

[19] P.M. Bhattacharya, S. Mukhopadhyay,R.K. Majumder, and J.R. Kayal, 3-D Seismic Structure of Northeast India Region and Its Implication for Local and Regional Tectonics. Journal of Asian Earth Sciences, Vol. 33 No. 1-2, 2008, pp. 25-41.

[20] D.R. Nandy, (2005): Geodynamics of Northeastern India and the adjoining region, Geological Survey of India, Spl. Pub. No. 85, 2005, pp 49-59.

[21] W.P. Chen and P. Molnar, (1990): Source parameter of earthquakes and interplate deformation beneath the Shillong plateau and the northern ranges, journal of Geophysical Research, Vol. 95, 1990, pp. 12527-12552. 